Semina $\square \quad \mathrm{Nr} 15$

Scientiarum 2016

s. $37-63$

DOI: http://dx.doi.org/10.15633/ss.1767

dr Diego Fusaro

\title{
Science of knowledge and historical experience
}

\section{The role of historiography in Fichte's Grundzüge}

\section{Introduction. The statute of historicity}

This paper sets out as its objective the exploration of some of the key passages and most relevant theoretical plexuses of the Grundzüge des gegenwärtigen Zeitalters ${ }^{1}$ by Johann Gottlieb Fichte devoted to the theme of historical narrative and, more generally, of historiography.

In particular, we will first of all aim to show the specific status of Historie according to the dictates of GZ, which will force us to refer, if only impressionistically, to other Fichtian works in which this issue is addressed. Secondly, we will try to outline the differences that GZ establishes between the functions of Wissenschaftslehrer and those of Historiker (historian), in an attempt to show, at the same time, the nexus linking the two and the activities they perform.

As has been underlined by many voices of Fichte-Forschung that idea of Geschichtsphilosophie constantly recurs, albeit in different ways and with different intensity, among the interests of Fichte. ${ }^{2}$ It

Further: GZ, 1806.

2 See R. Picardi, Il concetto e la storia: la filosofia della storia di Fichte, Bologna 2009 , pp. 62 ss. 
can not, after all, be forgotten that the thinker of Rammenau came on the public scene, after the Versuch einer Kritik aller Offenbarung of 1792 , with the two much debated Revolutionsschriften ${ }^{3}$ : their nucleus was built on a discussion of the event of the French Revolution, in a perspective in truth oriented to comprehend its import - evaluating its legitimacy and wisdom - more than proposing a specific place in the order of Weltgeschichte.

As argued by, among others, Giannino Di Tommaso in his important study Doctrine of science and the genesis of the philosophy of history in early Fichte ${ }^{4}$ (1986), the very structure of the Wissenschaftslehre praxologische Dialektik ${ }^{5}$ presents its inescapable relationship with the philosophy of history; a relationship which on Marco Ivaldo convincingly insisted, arguing that "the ethic infinite is the opening of a history of liberty," ${ }^{\circ}$ which is a series of indeducible actions, according to the order of time, corresponding to the efforts that reason expends to fully realise itself, to make sure everything correspond to it.

Thus, still in the words of Ivaldo, "history is the formation of freedom over time according to the idea." It corresponds to that "Creative formation which comes into being and accretes, mediating the interpersonal accomplishment of the task of freedom in time," 8 configuring itself as a process in which the "I" increasingly corresponds to the "non-I" and becomes more and more aware of its own destination and its true authentic nature as indivisible subject paradoxically existing in the fragmentation of the I empirical. The practical activity of the "I" is determined by concrete historical objectification along the mobile axis of history, breathing life into history as the history of freedom.

3 See M. Buhr, Revolution und Philosophie: die ursprüngliche Philosophie Johann Gottlieb Fichtes und die französische Revolution, Berlin 1965, pp. 15 ss.

4 See G.V. Di Tommaso, Dottrina della scienza e genesi della filosofia della storia nel primo Fichte, L'Aquila 1986.

5 See K. Hammacher, Fichtes praxologische Dialektik, "Fichte-Studien" 1 (1990), pp. 25-40.

M. Ivaldo, Libertà e ragione. L'etica di Fichte, Milano 1992, p. 190.

7 M. Ivaldo, Libertà e ragione. L'etica di Fichte, op. cit., p. 304.

8 M. Ivaldo, Libertà e ragione. L'etica di Fichte, op. cit., p. 303. 
In this perspective, the GZ can rightfully be considered as the most mature and aware expression of Geschichtsphilosophie, with respect to which the self-same Staatslehre (along with its important development of this theme) should be read in continuity. The GZ is configured, in fact, as the work on which the Fichtean philosophy of history must be measured, and this not only because it is the only monographic text dedicated to it, but also because, for the first time, the thinker of Rammenau is not limited to episodic considerations or developing impromptu reflections on the present, but constructs rigorously, a priori, on real historical topology, a precise fixing of Weltgeschichte, always understood - in line with the WL, in a framework uncontradicted by the presence of a Weltplan - as a series of free objectifications of human freie Wirksamkeit. ${ }^{9}$ This historical topology, as pointed out by Carrano, ${ }^{10}$ was actually the true aspect missing in previous Fichtian elaborations on the philosophy of history.

The main objective that the GZ responds to seems, then, to be two-fold. Fichte aims, on the one hand, to describe the present, emphasising in an unsweetened form all its major contradictions, and contextualizing it within the framework of Weltgeschichte and its five epochs deduced a priori from speculative reason. On the other hand, in a convergent way and always in line with the dictates of WL, the thinker of Rammenau aims to awaken his contemporaries from the torpor that causes in them a fatalistical, dogmatisch, acceptance of the age's "accomplished sinfulness" (vollendete Sündhaftigkeit) as, if you will, inescapable destiny, or as the perfect realization of human egotism, summarized in the axiomatic of do ut des. ${ }^{11}$

9 See S. Azzaro, Politica e storia in Fichte, Milano 1993, pp. 44 ss.

10 See A. Carrano, La storia come progresso e come ritorno, [in:] J. G. Fichte, Grundzüge des gegenwärtigen Zeitalters, 1806, [in:] Gesamtausgabe der Bayerischen Akademie der Wissenschaften [further: GA], Hrsg. R. Lauth, H. Jacob, StuttgartBad Cannstatt 1962 pp., I, 8; transl. in italian by A. Carrano, I tratti fondamentali dell'epoca presente, Milano 1999, pp. 22 ss.

11 See our essay La compiuta peccaminosità. La critica della società capitalistica nei "Grundzüge" di Fichte, in "Filosofia Politica" 1 (2013), pp. 97-116. 
In GZ, the description of the present sinfulness and all the fundamental milestones that punctuate the Weltgeschichte are still connected to, and, strictly speaking, subordinate to the requirement that dictates them as a moral task, so that the "cosmic plan" can be fulfilled and all relationships can unfold according to freedom and reason: the action stretching out to a transcendence of today and toward a pre-intended future.

Now, in view of the fact that they deal with the past also- precisely what was missing in the previous texts-the GZ cannot evade the inherent question of the theoretical relationship that binds historians to philosophers. ${ }^{12}$ It is, we must point out, a subject that, in truth, was already mentioned in other writings, but only here became central; to the point that Fichte insists on it several times, in several passages scattered throughout different Vorlesungen of GZ.

In particular, in the system of the GZ, Fichte's requirement under in the fourth Jena lesson on Bestimmung des Gelehrten 1794 is satisfied: the Gelehrter, 'scholar', was called to unite a virtuous, purely theoretical (philosophical) knowledge with the empirical (historical), seeking a fruitful synthesis between the two, i.e. a philosophical-historical knowledge. More precisely, the intellectual Gelehrter should possess - so say the Jena lessons on the scholar - a philosophical (a priori) knowledge of the needs of humanity as well as a philosophical and historical knowledge of the concrete means to satisfy them; as well as, finally, a historical knowledge that makes one aware of the past, the empirical data underpinning human progress which is taking place thanks to the concrete act of Gelehrter as an instructor of mankind. ${ }^{13}$ The passage of the Bestimmung des Gelehrten of Jena is worth quoting in its entirety:

The first kind of knowledge is based on mere rational and philosophical assumptions; the second is based partly on experience and is, there-

12 See M. Ivaldo, Zur Geschichtserkenntnis nach der Transzendentalphilosophie, "Fichte-Studien" 6 (1994), pp. 303-319.

13 C. Asmuth, Metaphysik und Historie bei J.G. Fichte, "Fichte-Studien" 23 (2003), pp. 145-158. 
fore, the history of philosophy (philosophisch-historisch) (not only historical, since the aims of this in any case could give only philosophical knowledge, I have to put them in connection with the objects experience gives me, so as to be able to consider the latter as a means to meet these purposes). This knowledge has to benefit the community (diese Kenntniss soll der Gesellschaft werden nützlich); then, it is not a matter of knowing, in general, what are the rules of man as such, and in what manner he can deploy them, because such knowledge would still always completely devoid of results. It has still to advance one step in order to be of benefit in concrete terms. We need to know what specific cultural level a given historical moment is at, the company of which you are a member, to which higher level it will rise and what instruments it can use in view of this objective. Well, certainly we can, moving from rational principles and taking as a prerequisite experience in general, the way to measure the human race, regardless of any specific experience. You can report in a truly approximate way the individual program and how much further that it will have to go before they reach a specific cultural stage. However, reporting the degree to which mankind has actually progressed at a certain moment in history is impossible it is moving only by rational principles. In this respect, it is necessary to resort to experience, you have to analyse the events of the past, but with a gaze made more acute by virtue of philosophy (aber die Stoves angeben, auf welcher es in einem wirklich bestimmten Zeitpuncte stehe, das kann man schlechterdings nicht aus blossen Vernunftgründen; darüber muss man die Erfahrung befragen, man muss die Begebenheiten der Vorwelt - aber mit einem durch Philosophie geläuterten Blicke - erforschen). You should look around and scrutinize your contemporaries. This last section of the knowledge essential for the company is therefore uniquely historical. ${ }^{14}$

As will be supported in his next Sittenlehre of Jena of 1798, "the intellectual, on the one hand, must know the subject of the culture

14 J. G. Fichte, Einige Vorlesungen über die Bestimmung des Gelehrten, 1794, [in:] J. G. Fichte, Sämmtliche Werke [further: SW], ed. by I.H. Fichte, Berlin 18451846, VI, p. 326. 
of his time, and on the other must develop it,"15 virtuously merging the three types of knowledge outlined in the lessons of Previous Bestimmung des Gelehrten.

You can, then, legitimately maintain that the GZ, for their part, aspire to achieve the "philosophical-historical" knowledge thematised in lessons on the scholar of 1794, transcending the empirical historical without depreciating it and, indeed, substantiating the a priori vision by putting it to use, that is, to show its stamp on the plane of concrete happening in which historical experience is condensed.

Moreover, the GZ, reclaiming the partition coded Bestimmung des Gelehrten of Jena, conduct a more careful and reasoned distinction between the tasks and the method of the philosopher and those of the historian, highlighting how the two figures should have a cooperative relationship: The first traces a priori a framework of historical development, deducing from the principles of reason steps in which the Weltgeschichte must be articulated in order to reach its telos. The second role, meanwhile, involves adeptly collecting and cataloguing the empirical material, to provide the first with concrete material with which to corroborate the a priori vision.

The philosopher is called - so says the Bestimmung des Gelehrten of Jena - to fix in place the telos of historical development, deducing from a priori principles of reason: this goal - says Fichte in the passage earlier cited - "may only be a philosophical knowledge,"16 where the empirical facts catalogued by the historian are only "tools to meet these objectives." 17

Now, if philosophical reason may indicate the telos, and the steps you need to take to achieve it (making possible ipso facto that a priori periodization of history thematized in GZ), it, nevertheless, is not able to report, alone, at what stage of development we actually find ourselves, in the present state. In the words of the Bestimmung des Gelehrten of Jena, if "we need to know which specific cultural

15 See J. G. Fichte, System der Sittenlehre, 1798; GA, I, 5, p. 303.

16 SW, VI, p. 326.

17 SW, VI, p. 326. 
level a given historical moment is at, the company of which you are a member," 18 well, this knowledge cannot be inferred a priori, but must be extrapolated from careful study of empirical reality.

It cannot, in other words, be the subject of philosophical speculation, but must be obtained from the empirical analysis of its real history. In fact, "to report the degree to which mankind has actually progressed at a certain moment in history is impossible moving only by rational principles" ${ }^{19}$ : these can only "chart the course the human race, regardless of any specific experience." ${ }^{20}$

Hence, in fact, the need, scattered throughout since 1794, to "make use of experience," 21 to "analyse the events of the past" 22 and to "look around and scrutinize their contemporaries." 23 This type of knowledge corresponds precisely to historical knowledge, the precise classification of events and accurate representation of reality.

The GZ remain faithful to this program, entrusting to the historian the task of exact chronological evenemential description, so that then the philosopher can, on that basis, understand at what stage of development weltgeschichtlich, outlined a priori, humanity lies: ${ }^{24}$ it is what, in fact, in the system of the GZ, allows the Wissenschaftslehrer to label the present time as a time of 'accomplished sinfulness', and therefore to fix precisely the epoch in which humanity is projected in the current state.

As already explained in the Bestimmung des Gelehrten, and as now taken up by Fichte in GZ, there is no way to catalogue the present time if not relying on its empirical description, with recourse to the support of historians ${ }^{25}$. Only in this way will it become possi-

18 SW, VI, p. 326.

19 SW, VI, p. 326.

20 SW, VI, p. 326.

21 SW, VI, p. 326.

22 SW, VI, p. 326.

23 SW, VI, p. 326.

${ }_{24}$ H. Heimsoeth, J.G. Fichtes Aufschliessung der gesellschaftlichgeschichtlichen Welt, Torino 1962, pp. 33 ss.

${ }_{25}$ J. Navarro-Pérez, Fichte, Humboldt y Ranke sobre la idea y las ideas historicas, "Anuario Filosofico" 30 (1997), pp. 405-426. 
ble to determine incontrovertibly in which of the five eras outlined a priori we are at the present time.

In light of this albeit cursory traversal of the decisive passages from Bestimmung des Gelehrten of Jena dedicated to the delineation of tasks between philosophers and historians, it becomes possible to argue that the GZ are structured exactly in accordance with the principles outlined in broad terms in 1794.

They take up that distinction and result in an in actu a priori vision making use of empirical knowledge provided by the work of the historian to decipher the actual stage in which humanity is projected and, therefore, to envisage an escape route out of it, entrusting it to the free will of finite rational entities guided by the educational work of the scholar. ${ }^{26}$ Knowledge of historical fact makes it empirically visible in the eyes of the philosopher that the present in which he thinks and acts is the time of vollendete Sündhaftigkeit.

The historicizing of the gaze is a subject on which the GZ insist thoroughly. They, on the one hand, draw attention to the fact that only historical knowledge can permit the a priori gaze of the philosopher to understand which age humanity actually inhabits at the present time. ${ }^{27}$ and on the other hand, they point out that only the historicizing perspective, and thus the showing of how the existing reality has its own history and is the outcome of a process punctuated by practice and possibilities, it becomes possible to criticize in the fullest sense the present by relating it as much to the past as to the future, and thereby reopening the sense of the possibility for transforming action.

It is not, in fact, possible to criticize the accomplished sinfulness of the present by "a vision from the perspective of this time,"28 explain the GZ. As long as you remain imprisoned by this view you cannot understand the contradictions: we are led to live it as a nat-

${ }_{26}$ See P. L. Oesterreich, Die Einheit der Lehre ist der Gelehrte selbst. Zur personalen Idee der Philosophie bei Johann Gottlieb Fichte, "Fichte-Studien" 16 (1999), pp. 1-18.

${ }_{27}$ I. Radrizzani, Quelques réflexion sur le statut de l'histoire dans le système fichtéen, "Revue de theologie et de philosophie" 1991, pp. 293-304.

28 GA, I, 8, p. 385. 
ural way of life, sensing its contradictions as if they were natural and eternal, not historically determined. As expressed in the second Vorlesung of GZ, "of the present epoch we can speak only in view of the present epoch," ${ }^{29}$ ending up, therefore, necessarily sanctifying it and fulfilling the function of the apologist.

For this reason, it is necessary, once again, to historicize the gaze projecting retrospectively to past ages and prospectively to future generations, so that today, far from being a standard to measure itself against, would be commensurate to other historical situations. As clarified in the second Vorlesung of GZ in relation to the present time, "no one who is not already beyond can characterize or can conceive a feature of the same." ${ }^{30}$

It is because of these considerations that science, of which philosophy must be the standard bearer "transcends all time and eras, as it encompasses a time and equates it to itself as the superior foundation of all times, subjecting them to its free interpretation," 31 and therefore intends the present not as the completion of history (neither as its aim-'end' nor as its finish-'end'), nor in the dogmatic manner as merely a given reality, natural and eternal.

The gegenwärtige Zeitalter corresponds, instead, to the point of passage in preparation for a redeemed future, finally marked by free relations, according to reason on a universal scale, such as to show this present for what it really is, a time of 'accomplished sinfulness'. ${ }^{32}$ It is also for this reason that the GZ, consistent with the praxologische Dialektik of the WL, do not just describe history in its tripartite division of past, present and future, but with descriptive elements of instances with highly prescriptive associations, aimed at ensuring that Vernunftwesen take action, and can finally realize the "cosmic plan" of history as a history of salvation.

29 GA, I, 8, p. 211.

30 GA, I, 8, p. 211.

31 GA, I, 8, p. 203.

${ }^{32}$ See J. Heinrichs, Die Mitte der Zeit als Tiefpunkt einer Parabel. Fichtes Geschichtskonstruktion und Grundzüge der gegenwärtigen Zeitenwende, "Fichte-Studien” 23 (2003), ff. 175-189, pp. 175-189. 


\section{Duties of the historian and duties of the philosopher}

It will be necessary to further clarify the specific status the Rammenau thinker assigned to history, as well as the distinction of tasks between historians and philosophers which is outlined - along the fundamental lines set down in Bestimmung des Gelehrten of Jenain the Vorlesungen 1804-1805.

We know that, in the pages of GZ, Fichte gives history a definite place in the context of WL as System der Freiheit. ${ }^{33}$ Knowledge, in his opinion, is set out into "empirical" and "a priori." In turn, however, the empirical knowledge differs in two fundamental ways: historical and physical. As for history, it falls to all intents and purposes, in the view of Fichte, into empirical knowledge, like physics, from which it also differs profoundly.

As suggested by Picardi, ${ }^{34}$ some passages of the nodal GZ are, in fact, devoted to the clarification of the relationship and differences between physics and history as parts of empirical knowledge $\mathrm{e}^{35}$ : physics deals with nature, which is "object eternally to equal to itself," 36 taking shape more precisely as "subsistent objective unity." ${ }^{37}$ History, in turn, corresponds to the "unitary concept" of the earthly life of mankind, and presents itself, therefore, as a "concept of a predetermined fulfilment (Erfüllung)" 38 of time. ${ }^{39}$

Elsewhere Fichte writes in the text that history is the "Science of the cascading event," 40 having as its object unrepeatable sensory impressions, ultimately spent, asking to be sent to those who have had no opportunity to get into direct contact with them. In the ninth Vorlesung of GZ, Fichte says, in a convergent way, that "such a his-

33 GA, I, 8, f. 297.

34 See R. Picardi, Il concetto e la storia: la filosofia della storia di Fichte, op. cit., pp. 32-33.

${ }_{35}$ R. Picardi, Il concetto e la storia: la filosofia della storia di Fichte, op. cit., pp. 32-33.

36 GA, I, 8, f. 297.

37 GA, I, 8, f. 297.

38 GA, I, 8, f. 197.

39 R. Picardi, Il concetto e la storia: la filosofia della storia di Fichte, op. cit., p. 32.

40 GA, II, 9, f. 145. 
tory a priori, just as the philosophy of nature [...] strives to find an a priori physics," ${ }^{41}$ that is, general laws that allow for the understanding and contextualization of the empirical level of happening.

Following the discussion of Fichte, it could probably be argued that history is set up, so to speak, as a kind of physics of human events. His chief object consists of the given facts and empirical events that are not deducible ordine geometrico and appear as data ascertainable experientially. For the Historiker, "history is mere empiricism; it has only to provide the facts and all of its evidence can be adduced only factually." ${ }^{22}$ The argument is central in GZ, but is also expressed in the crepuscular Staatslehre 1813, where Fichte writes the following:

What is history in general? We start from the best known and general. It offers a datum, as contingent, i.e. not based on any law, cannot be known a priori. ${ }^{43}$

History, then, is related to the dimensions of what is, in essence, contingent, and non-deducible a priori, i.e. with the objectification of free human practice. As such, these are contingent and not necessitated, and therefore present themselves as non-deducible by philosophical reasoning. They can only be reconstructed empirically, as the factual objectivised product of freedom.

The GZ insist on a clear division of tasks, assumptions and interests between the two different vocations of the historian and philosopher. This is what the GZ themselves explicitly define as "the long-running dispute between philosophy and history." ${ }^{44}$

In addition to the already mentioned second lesson of the Bestimmung des Gelehrten of Jena in 1794, it is also to be found in the centre of Beitrag and its considerations on the scope weltgeschichtlich of the French Revolution. So wrote Fichte pages of Beitrag:

\footnotetext{
41 GA, I, 8, f. 301.

42 GA, I, 8, f. 301.

43 SW, IV, f. 460.

${ }_{44}$ GA, I, 8, f. 306.
} 
Experience in itself is a box full of characters thrown confusedly on each other; only the human spirit is what brings a sense in this chaos, from which they put together an Iliad here and there a historical drama in the genre of Schenkert. ${ }^{45}$

Albeit metaphorically, Fichte is here thematizing the differencelater developed further - between the patient and accurate recollection of the events and the ability, not deducible from mere empirical sequence of events, to give meaning to those events; in the sense that-as we must insist - it can not be derived from the events themselves empirically and that, at the same time, it is the only guarantee that they do not become disconnected in pure episodic nature of their occurrence.

According to an issue that, as noted by Reinhart Koselleck, ${ }^{46}$ features prominently in the debate of the time, Fichte uses the image of the letters of the alphabet and the novel. The individual historical events collected by Historiker are the equivalent of the letters of the alphabet. In itself, not sufficient to create a completed novel, endowed with sense. For this to happen, the letters are certainly necessary, but not sufficient. Areas should be carefully linked together via a sense that cannot be derived from them and which, nonetheless, could not express themselves in their absence.

It is up to the philosopher then to impose the rites-of-passage narrative structure on history as a process endowed with meaning, where individual events must be seen as parts of a whole that can return them their full meaning, which they, taken in and of themselves, are without. ${ }^{47}$

Beyond the metaphor of the book, it is crucial to emphasize that Fichte, from the days of Beitrag, distinguishes between tasks of the historian and those of the philosopher, assigning the second

${ }^{45}$ J. G. Fichte, Beitrag zur Berichtigung der Urtheile des Publikums über die französische Revolution, 1793-1794; SW, VI, f. 70.

${ }_{46}$ R. Koselleck, word Geschichte, [in:] R. Koselleck, W. Conze and O. Brunner, Geschichtliche Grundbegriffe. Historisches Lexikon zur politisch-sozialen Sprache in Deutschland, Stuttgart 1972-1997, 9 vol., II, pp. 677 ss.

47 R. Koselleck, word Geschichte, op. cit., pp. 678 ss. 
undoubtedly superior importance, but not to deny the importance of the first. Picardi has, in this regard, spoken - especially in reference to the GZ, which take up the theme, (albeit in a framework that shall decidedly become the core of Beitrag) - of a "rigid division of labour between the positive historian and philosopher, with a clear subordination of the first to the second." ${ }^{48}$

The philosopher outlines a priori the Bildungsroman of mankind, using some of the "letters" made available by the valuable work of the historian, but without relying on them. His work remains free and, in its basic structure, independent of all experience. Again in the words of Picardi: "to the empirical historian Fichte assigns only the task of verifying and transmitting facts," 49 whereas the philosopher, however, is entrusted with the duty of deciphering the hieroglyphs of the historical dynamic, its immanent sense, compared to which individual events are nothing more than pieces of evidence.

Without the a priori perspective of philosopher, empirical facts remain silent, just like the letters of the alphabet not connected in order to form a work of meaning. It is also, we could say in the wake of Lauth, ${ }^{50}$ a transcendental vision of the historical course, in favour of which the a priori vision makes intelligible those historical facts that, in its absence, would remain "blind experience," letters disjointed and meaningless.

Since the early writings, Fichte believes what the GZ expresses in the clearest and most explicit form: the work of historians is insufficient, because, in their Geschichtsschreibung, they are deprived of a holistic theory, capable of transcending the narrow parameters of the empirical. ${ }^{51}$

For their part, the philosophers are able to decipher, behind the rhapsody of chaotic events, a deep unity, in turn able, once under-

48 R. Picardi, Il concetto e la storia: la filosofia della storia di Fichte, op. cit., p. 57.

49 R. Picardi, Il concetto e la storia: la filosofia della storia di Fichte, op. cit., p. 57.

50 See R. Lauth, Il pensiero trascendentale della libertà: interpretazioni di Fichte, ed. by M. Ivaldo, Milano 1996, pp. 43 ss.

${ }_{51}$ SW, VI, f. 68. See R. Picardi, Il concetto e la storia: la filosofia della storia di Fichte, op. cit., pp. 23-72; C. De Pascale, Vivere in società, agire nella storia: libertà, diritto, storia in Fichte, Milano 2001, pp. 101 ss. 
stood, to give an account of individual events apparently unrelated. So in GZ:

Conceiving in clear concepts what is absolute, universal and eternally equal to itself in guidance of the human race, is that of the philosopher. Establishing the facts of the ever precarious and changeable sphere on which it advances that stable course, is that of the historian, from whom the philosopher recalls the passage of discoveries. ${ }^{52}$

Hence the firm conviction of the GZ about the fact that "the particular historical fact can be understood only through 'history in general', that is, the a priori construction attainable by the philosopher." ${ }_{53}$ As has been suggested, in GZ and other texts in which address the Geschichtsschreibung, "the recognition of this positive role and indispensable activity of the historical empirical is joined to the belief that it is not self-sufficient, but represents only the base material for a work of interpretation that requires as a prerequisite an a priori key." ${ }^{4} 4$ In the GZ, this perspective is maintained and, further, set out in more articulated form, from a fully transcendental point of view, that at the time of Beitrag was still missing.

It should then be remembered that already in the pages of $\mathrm{Bei}$ trag Fichte had explicitly expounded this thesis, now more systematically set out in GZ. Thus he wrote about the importance assigning custody of history to the universalizing action of the philosopher ${ }^{55}$ :

It's necessary to be entrusted to the care of the true philosopher, so that they may give easy proof that, in this colourful puppet show, which attracts your eye with its colours, all avenues have been tried and none led to the goal, and so you cease to discredit his way, the way of ratio-

52 GA, I, 8, pp. 305-306.

53 R. Picardi, Il concetto e la storia. La filosofia della storia di Fichte, op. cit., f. 17 .

${ }^{54}$ R. Picardi, Il concetto e la storia. La filosofia della storia di Fichte, op. cit., f. 57 .

55 See S. Azzaro, Politica e storia in Fichte, op. cit., p. 46. 
nal principles, in comparison to your own, the way of the blind experiment; It must be entrusted to his care, so he uses it to draw in red some letters, in the alphabet that you have to learn, so that you can recognize the colour for now, until finally you have learned to recognize them by their intrinsic character. ${ }^{56}$

Where the eyes of the historian record the individual standalone letters, the lenses of interpretation of the philosopher are able to put them together and build propositions which concentrate the meaning of the great book of history.

The simple evenemential narrative, typical of historians, must therefore give way to the work of the philosopher, whose interests orbit around the problem of the significance of historical happening uniformly understood as a carrier of an immanent sense, and can justify even individual events.

\section{Particular historical, universal philosophical}

Since the early writings, the assumption - to which Fichte always remains faithful - of the division of labour between historians and philosophers, with the assignment of primacy to the latter, does not imply in any way a rejection of the role of Historiker, as sometimes some interpreters have argued unjustifiably. ${ }^{57}$

Such prejudice, based on excessive faith attributed to the previously recalled anecdote that the thinker of Rammenau would rather count peas than study history, is found, for example, in Christoph Asmuth and his work Metaphysik und Historie beautiful JG Fichte ${ }^{58}$ (2003), and then also in Klaus-Michael Kodalle and in his essay on Das Stellenwert der Historiographie im Kontext des Fichtheschen

56 SW, VI, f. 68. See K. M. Kodalle, Das Stellenwert der Historiographie im Kontext des Fichtheschen Geschichtsdenkens "Fichte-Studien" 11 (1997), pp. 247-280.

${ }_{57}$ See K. M. Kodalle, Das Stellenwert der Historiographie im Kontext des Fichtheschen Geschichtsdenkens, op. cit., 279-280.

58 C. Asmuth, Metaphysik und Historie bei J. G. Fichte, op. cit., pp. 145-158. 
Geschichtsdenkens ${ }^{59}$ (1997). These are very different texts, in historiographical assumptions and conclusions, but they are united by the write-down of the historical narrative in the work of Fichte.

In contrast to the interpretations of Asmuth and Kodalle, we know that Fichte, within certain limits, always valued work of Historiker, considering it essential, if not alone sufficient. As we have seen, following an interpretative line that virtually connects $B e i$ trag to GZ and Staatslehre, only the a priori vision which is the hallmark of Wissenschaftslehrer can assign the full meaning to factual data. This is, after all, merited by the historian's skill in collecting data with adept care and precision: the history of historians - as WL 1804 puts it - corresponds to the "pure understanding of the multiple as such, in its factuality." 60

This is not to deny, of course, that, in several places of his work, Fichte ends up outlining unilaterally, simplistically and almost in caricature the historian's task, presenting it as a simple display impartial and unthinking - of events. Thus, for example, in the ninth Vorlesung of GZ:

From this it follows certainly, as it must, that the collator of simple facts (der Sammler der blossen Facten), whose office, for all its opposition to philosophy, it is not insignificant, but extremely respectable (höchst ehrwürdig), if only It is exercised properly. These have absolutely no support, no theme and no real fixed point outside of the succession of the years and centuries, without reference to their content; and he shall enter all that is historically established in one of these periods. He is a chronicler (und alles, was in einer dieser Zeitepochen historisch auszumitteln ist, muss er angeben. Er ist Annalist). ${ }^{61}$

"Collator of simple facts," and lacking any "theme" or "fixed point" outside of mere succession in the order of time, the Historiker - al-

59 K. M. Kodalle, Das Stellenwert der Historiographie im Kontext des Fichtheschen Geschichtsdenkens, op. cit., pp. 274-280.

60 GA, II, 8, f. 8.

61 GA, I, 8, f. 305. 
though presented so incontrovertibly in simplistic reductionism plays, for GZ, a role that is "highly respectable," by serving the universalizing action of the philosopher. This means, then, that for Fichte between the two figures exists a relationship of undeniable diversity, but also necessary cooperation.

The superior wisdom of the philosopher does not imply or justify, for Fichte, its reoccupation of the role of the historian. on the contrary, the first is called to avail himself of the empirical details and facts collated by the historian, to be able, in this way to support the a priori vision of the weltgeschichte.

It's certain that, as suggested by Picardi, ${ }^{62}$ Fichte, from beginning to end of his Denkweg, limits the usefulness of historical knowledge only to the scholars: that is, to those who know how to furnish it with the philosophical view: as if, in fact, historical knowledge, though essential, would acquire its validity only if accompanied by the vision of the philosopher and placed under the guardianship of his a priori gaze.

As has been suggested, ${ }^{63}$ in outline ng the tasks of the historian and his work of Geschichtsschreibung, GZ does nothing but repeat, albeit in an original way, the central thesis of the then dominant historiographical model of "pragmatic history," i.e. the historical investigation according to the theory of causation.

In this regard, however, its necessary to pay close attention to the words, to avoid misunderstandings that would compromise the understanding of speech. In the ninth lesson of GZ, Fichte describes pragmatic history as "historical art," using an expression that Schelling, in Vorlesungen über die Methode des Akademischen Studiums (1803), used, but with a diametrically opposed sense. ${ }^{64}$ In particular, in the text of 1803, Schelling had targeted strictly pragmatic history, opposing to it the method of a "historical art" differently un-

62 R. Picardi, Il concetto e la storia. La filosofia della storia di Fichte, op. cit., p. 68 .

63 R. Picardi, Il concetto e la storia. La filosofia della storia di Fichte, op. cit., p. 55 .

${ }^{64}$ F. W. J. Schelling, Vorlesungen über die Methode des Akademischen Studiums, [in:] F. W. J. Schelling, Ausgewählte Schriften, Frankfurt a.M. 1985, II, pp. 310-311. 
derstood, and more specifically conceived as an artistic treatment of the historical material, according to a method in some ways not far from what would later be proposed by Humboldt in Über die Aufgabe des Geschichtsschreibers (1821). For its part, Fichte, as seen, for the "historical art" means "pragmatic history," conceived in the manner stated above. ${ }^{65}$

The difference between the historian and the philosopher, as already suggested, is in the fact that the first remains permanently attached to the empirical plane, while the second refers to it only in passing, to support his a priori vision. In the words of the ninth lesson of GZ, "the simple empirical historian must faithfully conceive all these elements, as they are found, and juxtapose them. To the philosopher, who uses history to that intent which here is ours, belongs only the last element, truly civilization in its living progression, and puts to one side everything else." ${ }^{66}$ So writes Fichte in the ninth GZ, specifying the use that he himself is making of the historical narrative as part of his lectures:

To state the very real relationship (das wahre Verhältniss) that runs between the philosopher and the historian: the philosopher deigns to tell the truth of history only to the extent that it serves its purpose (nur, inwiefern sie zu seinem Zwecke dient), ignoring all that is not needed in this regard. And frankly I announce that I shall not avail myself of such in following my research. ${ }^{67}$

It is also in the light of this strict disciplinary division of labour between the historian and philosopher that, in GZ, Fichte is taking part in one of the great debates that animated the last decades of the eighteenth century about the possibility of establishing what was the method suitable for the interpretation of Genesis.

Historical evenemential inquiry can not examine in any way the beginnings of human history, as they cannot be established empiri-

${ }_{65}$ See K. Okada, Fichte und Schelling, "Fichte-Studien" 21 (2003), pp. 45-52.

66 GA, I, 8, p. 305.

67 GA, I, 8, p. 305. 
cally: "if man was created in time, then, at least with his conscience, he did not take part, and he could not see how the past is not being, nor can pass it down to posterity as a posteriori fact." ${ }^{68}$ Nor is it possible to make concessions to the theories - and here Fichte is targeting both the Linnaeus' Systema Naturae, and the Encyclopédie - that classify homo sapiens in the order of primates, making a "descendent ultimately from an orang-utang, a Leibniz or Kant." 69

Philosophy can instead seek to venture into this field removed from the empirical factuality, precisely because of the fact that, according to a priori oriented schemes, it is not required to give an account of concrete historical experience and the level of empirical factuality.

In particular, the philosophical view is called to accept a mythical explanation of the book of Genesis as only possible explanation. ${ }^{70}$ So in the ninth lesson of GZ:

What are now the conditions of the empirical existence, what then is a prerequisite for the mere possibility of a history in general, and what is to be put before everything, before the story can even find its beginning, are matters for the philosopher. [...] Neither the philosopher nor the historian, therefore, have something to say about the origin of the world and of mankind (über den Ursprung der Welt und des Menschengeschlechtes), since there is generally no source, but only the 'only timeless and necessary. Being' But the philosopher must give an account of the factual conditions of existence (die Bedingungen des factischen Daseyns) as precisely excess of any factual existence and every empirical. ${ }^{71}$

Genesis, in fact, is for Fichte a mere "philosopheme," 72 devoid of any historical value. ${ }^{73}$ It, however, is heuristically fruitful, because

68 GA, I, 8, p. 298.

69 GA, I, 8, p. 299.

70 R. Picardi, Il concetto e la storia. La filosofia della storia di Fichte, op. cit., pp. 177-178.

71 GA, I, 8, pp. 297-298.

72 GA, I, 8, p. 298.

73 GA, I, 8, p. 298. 
it allows you to bring reason to bear, albeit only conjecturally, on historical events.

If, as has been shown, for Fichte the historian deals with the factual, where the philosopher is of the order of a priori, and therefore also of "what is a prerequisite for the possibility of every story,"74 then it is consistent according to his responsibility for fixing the elements of Urgeschichte, i.e. the pre-historical dimension that should be taken as a precondition for any ability to give an account of the empirically verifiable course of history. ${ }^{75}$ Again, only the philosopher can legitimately deal with Genesis.

The GZ try to set some of the conditions that it is the task of the philosopher to identify ${ }^{76}$. Among these, the first corresponds to the existence of humanity. The birth of the latter escapes the grasp of historical survey, because humanity is, by its nature, a manifestation of the phenomenal "only timeless and necessary Being." 77

The second one corresponds to social life. It too is an originating fact of history, not be investigated empirically. There is, in this regard, an interesting conceptual reorientation in respect to the Jena years, that here we can only mention and on which Picardi has widely focused attention ${ }^{78}$ : in a strengthening of the community perspective identified by Aldo Masullo as one of the most specific features of Fichtean reflection, ${ }^{79}$ in GZ it is postulated as a precondition and as original fact of history which was, for example, in Naturrecht of Jena (1796-1797) deduced on a social impulse basis. Finally, the third condition focused in GZ corresponds to language, condicio sine qua non of any forms of social coexistence of finite rational entities, according to a theme, already developed in Von der Sprachfähigkeit und dem Ursprung der Sprache (1795), and to be

74 GA, I, 8, p. 298.

75 GA, I, 8, p. 298.

${ }^{76}$ R. Picardi, Il concetto e la storia. La filosofia della storia di Fichte, op. cit., p. 180 .

77 GA, I, 8, p. 296.

78 R. Picardi, Il concetto e la storia. La filosofia della storia di Fichte, op. cit., pp. 132 ss.

79 See A. Masullo, Fichte: l'intersoggettività e l'originario, Napoli 1986, p. 140. 
returned to a central position in the subsequent Reden an die deutsche Nation.

In this way, Fichte further clarifies the by no means linear relationship established between, especially in GZ, historians and philosophers. Nor should it, in this regard, be forgotten that the lessons of the 1804-1805 open precisely with a discussion of this delicate theoretical problem, which reveals the absolute centrality that it occupies within the geschichtsphilosophisch reflections of the Rammenau thinker. After outlining, with a detailed table of contents, the general plan, outlining in broad strokes the content of the seventeen Vorlesungen of which it consists, Fichte, with the first lesson, immediately enters in medias res, addressing the issue of the relationship between historians and philosophers.

If it is true - as the first lesson says - that the GZ develop "a single thought which in itself constitutes an organic unity," 80 it's necessary, from the start, to clear up any possible misunderstanding. The GZ constitute a work structurally geschichtsphilosophisch, and therefore not as an empirical history text. More precisely, "what you are promised in these conferences is a philosophical framework of the present age." 81

This means, in fact, that the Vorlesungen as heard from the audience or the book in the hands of the reader should not be understood as the outcome of the work of the "mere empiricist," ${ }^{2}$ which is limited to the contingency and factual description.

If, for Historiker, individuals and their empirically proven actions are of paramount importance, for Wissenschaftslehrer they are not in the foreground, for he accesses a deeper dimension, located below the chaotic streaming and sprawling of events and major historical figures:

Individuals vanish entirely in the eyes of the philosopher (Individuen verschwinden nun aber vor dem vollends Blicke des Philo-

\footnotetext{
80 GA, I, 8, p. 195.

81 GA, I, 8, p. 196.

82 GA, I, 8, p. 196.
} 
sophen) and they all converge for him in one great community. Its feature captures everything with an acumen and consistency that may never reach the eternal wave of reality; as it does not touch any person, without ever falling into the portrait, it remains in the sphere of the idealized painting. ${ }^{83}$

From the first pages of this overture of GZ, Fichte insists on the already mentioned difference between the philosopher and historian, making clear the need, from the first, to operate regardless of experience from which the latter can never distance itself:

The philosopher that poses the task of such a description will seek a concept of the age regardless of any experience (unabhängig von aller Erfahrung einen Begriff des Zeitalters), which as a concept can not appear in any experience, and will expose the ways in which this concept appears in the experience, as necessary phenomena of this age (nothwendigen Phänomene dieses Zeitalters). ${ }^{84}$

For this same reason, having to a priori outline the sense of history, the philosopher - according to Fichte - "has absolutely no need of any experience for his office, that he exercises philosophy, remaining strictly within its boundaries, without regard to a any experience and simply a priori." ${ }^{55}$ So that he "must be able to describe in advance the whole era and all possible ages that are included," 86 deducing rationally. For this, the GZ must be understood as a work of philosophy of history and not of Geschichtsschreibung.

As pointed out, the level of empirical history can, at best, help the philosopher to support his argument and to understand what actual stage of history, designed from the outset, humanity is in at the present time. The philosopher is, therefore, called upon to take care not of the individual episodic events, but on their conditions of

\footnotetext{
83 GA, I, 8, p. 203.

${ }_{84}$ GA, I, 8, p. 196.

85 GA, I, 8, p. 196.

86 GA, I, 8, p. 196.
} 
possibility and the sense that secretly connects them, deciphering the hieroglyphs of the historical dynamic qua talis regardless of the size of the prosaic empirical factuality ${ }^{87}$ :

The philosopher, as far as he is concerned with history, follows a priori that continuous thread of the universal plan which for him is clear regardless of any history (geht jenem a priori fortlaufenden Faden des Weltplanes nach, der ihm klar ist ohne to Geschichte); and the use he makes of history is by no means to prove something by it, since his theses have already been proven before and independently of any history (seine Sätze und schon früher unabhängig von aller erwiesen Geschichte sind), but it is just to illustrate the history and to demonstrate the actual life that one understands without recourse to history (was auch ohne sich die Geschichte versteht). ${ }^{88}$

The philosopher, then, ponders rationally the concepts of the age, putting it in connection with the historical totum and drawing it rationally, always on a transcendental plane, to the knowledge of the whole, so that its parts join as a consistent development of the unified idea, and therefore the logic of history as such.

The historian has to collect the fullest extent possible, accurate and correct data, because his is empirical knowledge. But "this way of proceeding is not up to the philosopher, which would be absolutely reprehensible in the simple historical inquiry." 89 As with the historian, so the philosopher must respect the truth, but not in the same way.

The first has to recount exactly what happened, while the second is called to reconstruct the truth: the meaning of the historical process. He must not lie, but can not be accused of ommision: in fact, "he would be worthy of criticism only if he has claimed that

87 See C. De Pascale, Vivere in società, agire nella storia. Libertà, diritto, storia in Fichte, op. cit., p. 104.

88 GA, I, 8, p. 304.

89 GA, I, 8, p. 305. 
which never happened," but "does not deserve blame if he is silent because it certainly happened." 90

For his part, the historian collects exactly the empirical phenomena in their evenemential succession, but is not able to coordinate them in the light of the principle that makes them possible, and of which the Historiker remains clueless: "everything that becomes the principle of the phenomenon, becomes precisely what is lost in the phenomenon, and becomes invisible to the external sense and is not perceived even to the sharpest reflection," ${ }^{91}$ which is the reflection of the philosophical order.

\section{Summary}

\section{Science of knowledge and historical experience. The role of historiography in Fichte's Grundzüge}

This paper sets out as its objective the exploration of some of the key passages and most relevant theoretical plexuses of the Grundzüge des gegenwärtigen Zeitalters (1806) by Johann Gottlieb Fichte devoted to the theme of historical narrative and, more generally, of historiography. In particular, we will first of all aim to show the specific status of Historie. Secondly, we will try to outline the differences that Grundzüge establishes between the functions of Wissenschaftslehrer and those of Historiker, in an attempt to show, at the same time, the nexus linking the two and the activities they perform.

Keywords Fichte, history, science, philosophy, action

\section{Bibliography}

L'action historique d'après la philosophie transcendentale de Fichte, "Bulletin de la Société Française de Philosophie" (1976) 2, pp. 41-84.

Asmuth C., Metaphysik und Historie bei J.G. Fichte, "Fichte-Studien" 23 (2003), pp. 145-158.

Barbaríc D., Fichtes Gedanken vom Wesen der Sprache, "Fichte-Studien" 19 (2002), pp. 213-222.

90 GA, I, 8, p. 305.

91 GA, I, 8, p. 364. 
Becker F. J. E., Freiheit und Entfremdung bei Fichte, Marx und in der kritischen Theorie, Köln 1972.

Cantoni A., La filosofia e la teoria della storia di Fichte, "Rendiconti dell'Istituto Lombardo di Scienze E Lettere, Classe di Lettere" 1941-1942, pp. $115-131$.

Cantoni A., La "Teoria della scienza" del 1798 di G.A. Fichte, "Il Pensiero" III (1958) 1, pp. 51-68.

Cantoni R., Fichte e la filosofia della storia, "Studi Filosofici” 1944, pp. 25-58 [reedition: Mito e storia, Mondadori, Milano 1953, pp. 3-49].

De Pascale C., Le origini teoriche dei "Discorsi alla nazione tedesca”. La filosofia della storia di Fichte nel primo periodo berlinese, "Studi Senesi" 1977, pp. 39-103.

Di Tommaso G.V., Dottrina della scienza e genesi della filosofia della storia nel primo Fichte, L’Aquila 1986.

Duso G., Contraddizione e dialettica nella formazione del pensiero fichtiano, Urbino 1974.

Goddard J. C., Le Christ et l'histoire dans la "Staatslehre" de 1813, "Revue de Metaphysique et de Morale” 1996, pp. 71-83.

Hartkopf W., Die Dialektik Fichtes als Vorstufe zu Hegels Dialektik, "Zeitschrift für Philosophische Forschung" 1967, pp. 173-207.

Heimsoeth H., J. G. Fichtes Aufschliessung der gesellschaftlichgeschichtlichen Welt, Torino 1962.

Heinrichs J., Die Mitte der Zeit als Tiefpunkt einer Parabel. Fichtes Geschichtskonstruktion und Grundzüge der gegenwärtigen Zeitenwende, "Fichte-Studien" 23 (2003), pp. 175-189.

Hirsch E., Christentum und Geschichte in Fichtes Philosophie, Tübingen 1920.

Holz H., Die Struktur der Dialektik in den Frühschriften von Fichte und Schelling, "Archiv für Geschichte der Philosophie" 1970, pp. 71-90.

Ivaldo M., Zur Geschichtserkenntnis nach der Transzendentalphilosophie, "Fichte-Studien" 6 (1994), pp. 303-319.

Ivaldo M., L'approccio pratico-etico alla storia nella filosofia trascendentale di Fichte, [in:] Filosofia trascendentale e destinazione etica. Indagini su Fichte, a cura di A. Masullo, M. Ivaldo, Milano 1995, pp. 199-224.

Ivaldo M., Politik, Geschichte und Religion in der Staatslehre von 1813, "Fichte-Studien" 11 (1997), pp. 209-227. 
Kodalle K. M., Das Stellenwert der Historiographie im Kontext des Fichtheschen Geschichtsdenkens, "Fichte-Studien” 11 (1997), pp. 247-280.

Lask E., Fichtes Idealismus und die Geschichte, Tübingen-Leipzig 1902 [later collected in: Gesammelte Schriften, I, Tübingen 1923].

Lauth R., Der Begriff der Geschichte nach Fichte, "Philosophisches Jahrbuch" 72 (1965), pp. 353-384.

Lauth R., La costituzione trascendentale dell'esperienza sociale, "Humanitas" 1989, pp. 682-698.

Lauth R., Le véritable enjeu des discours à la nation allemande de Fichte, "Revue de Théologie et de Philosophie” 41 (1991), pp. 249-273.

Lendvai F. L., Die Wissenschaftslehre Fichtes im Zusammenhang mit seiner Geschichts- und Religionsphilosophie, "Fichte-Studien" 11 (1997), pp. 229-240.

Merker N., Fichte als Jakobiner: wie die politische Fichte zu lesen ist, [in:] Deutsche Klassik und Revolution, Hrsg. P. Chiarini, W. Dietze, Roma 1981, pp. 265-276.

Navarro-Pérez J., Fichte, Humboldt y Ranke sobre la idea y las ideas historicas, in "Anuario Filosofico", n. 30 (1997), pp. 405-426.

Navarro-Pérez J., Das Bewusstsein als Zeichen. Anmerkungen über Fichte und einige Strömmungen der Gegenwartphilosophie (G. Abel und J. Simon), "Fichte-Studien" 16 (1999), pp. 391-405.

Neuhouser F., Fichte's theory of subjectivity, Cambridge 1990.

Picardi R., L’idea di equilibrio di potenza nel pensiero storico-politico di Fichte, "Il Pensiero Politico" 1 (2003), pp. 48-82.

Picardi R., Teodicea, ottimismo e figure del male nel pensiero fichtiano, "Annali di Studi Religiosi" 6 (2005) pp. 183-218.

Picardi R., Sittliche Natur und Geschichte beim frühen und späten Fichte, "Fichte-Studien" 29 (2006), pp. 111-120.

Picardi R., Origine della cultura e "Urgeschichte" nella filosofia della storia di Fichte, [in:] AA. VV., La civetta di Minerva, Pisa 2007, pp. 129-164.

Picardi R., Necessité divine, contingence historique et liberté humaine: Les caractères de l'époque actuelle et la Doctrine de la Science 1804-II, [in:] L'Être et le phénomène. La Doctrine de la Science de 1804 de J. G. Fichte, red. J. C. Goddard e A. Schnell, Paris 2009, pp. 393-404. 
Picardi R., Il concetto e la storia: la filosofia della storia di Fichte, Bologna 2009.

Picardi R., La fondazione della scienza storica: Schleiermacher a confronto con Fichte, "Humanitas" 65 (2010) 4, pp. 683-698.

Picardi R., Nation - Gesellschaft - Individuum. Fichtes politische Theorie der Indentität, "Fichte-Studien" 40 (2012), pp. 123-147.

Picardi R., Geschichte und europäische Identität bei Fichte, "Fichte-Studien" 41 (2012), pp. 131-155.

Picardi R., The "Guiding Thread" of universal history: Kant's legacy in Fichte's philosophy of history, [in:] Kant und die Philosophie in weltbürgerlicher Absicht. Akten des XI. Kant-Kongresses 2010, Hrsg. S. Bacin u.a., Berlin 2013, pp. 817-830.

Radrizzani I., Quelques réflexion sur le statut de l'histoire dans le système fichtéen, "Revue de Theologie et de Philosophie" 1991, pp. 293-304.

Radrizzani I. et alii, La philosophie de l’histoire chez Fichte, Paris 1996.

Rompp G., Ethik des Selbstbewusstseins. Der Andere in der idealistischen Grundlegung der Philosophie: Kant, Fichte, Schelling, Hegel, Berlin 1999.

Roy M., La doctrine de la science de Fichte: idéalisme spéculatif et réalisme pratique, Paris 2010.

Salvucci P., Fichte e la storiografia, "Giornale Critico della Filosofia Italiana" 1963, pp. 208-254.

Schüttler H., Freiheit als Prinzip der Geschichte: die Konstitution des Prinzips der Geschichte [...] nach J.G. Fichtes Wissenschaftslehre, Würzburg 1984.

Steimbeck W., Das Bild des Menschen in der Philosophie J. G. Fichtes, München 1938.

Tagliavia G., Ragione e libertà nella storia, "Giornale di Metafisica" 20 (1998), pp. $473-488$.

Traub H., Fichte und seine Zeit, Amsterdam 2003.

Wallwitz G., Fichte und das Problem des intelligiblen Fatalismus, "Fichte-Studien” 15 (1999), pp. 121-145.

Zöller G., War without peace within Fichte's political appropriation of Machiavelli and its contemporary context in Herder and Hegel, "Rivista di Filosofia” 1 (2015), pp. 77-98. 